\title{
High concentrations of crude glycerin on ruminal parameters, microbial yield, and in vitro greenhouse gases production in dairy cows
}

\author{
E.H.C.B. van Cleef, J.B.D. Sancanari, Z.F. Silva, A.P. D’Aurea, V.R. Fávaro, F.O.S van Cleef, \\ A.C. Homem Júnior, and J.M.B. Ezequiel
}

\begin{abstract}
Holstein cows were used to evaluate the inclusion of elevated concentrations of crude glycerin on ruminal parameters, production of greenhouse gases, and microbial yield. The use of up to $300 \mathrm{~g} \mathrm{~kg}^{-1}$ reduces ruminal bacteria yield and $\mathrm{NH}_{3}-\mathrm{N}$, without affecting the $\mathrm{pH}$. Moreover, $300 \mathrm{~g} \mathrm{~kg}^{-1}$ glycerin increases methane production.

Key words: bacteria, glycerol, dairy cow, methane, microorganism.

Résumé : Les vaches holsteins ont été utilisées pour évaluer l'ajout de concentrations élevées de glycérine brute sur les paramètres du rumen, la production des gaz à effet de serre et le rendement microbien. L'utilisation d'une quantité jusqu'à $300 \mathrm{~g} \mathrm{~kg}^{-1}$ réduit le rendement bactérien du rumen ainsi que le $\mathrm{NH}_{3}-\mathrm{N}$, sans effet sur le pH. De plus, $300 \mathrm{~g} \mathrm{~kg}^{-1}$ de glycérine augmente la production de méthane. [Traduit par la Rédaction]

Mots-clés : bactéries, glycérol, vache laitière, méthane, microorganisme.
\end{abstract}

The advent of biodiesel due to the change in world's energetic matrix generates new residues and by-products, such as crude glycerin. Approximately $10 \%$ of total biodiesel produced become crude glycerin. This by-product has been intensively tested as energy source in diets for livestock. The glycerol (main constituent of crude glycerin) can be converted to glucose by the liver and kidneys to provide energy for cellular metabolism. In ruminants, the glycerol is fermented in the rumen into short chain fatty acids, mainly to propionic and butyric. In general, the inclusion of crude glycerin involves the concomitant removal of energy ingredients from diets, such as corn grain. Thus, in addition to increasing the availability of corn for human consumption, it could also interfere with the emission of greenhouse gases, particularly methane. As glycerol seems to be fermented mainly into propionic and butyric acids and not into acetic acid (Rémond et al. 1993), which is the main precursor of ruminal methane, a mitigation of the production of this pollutant is also expected.
However, the impact of crude glycerin on rumen parameters and microbial mass is not completely elucidated, especially when the addition is greater than $150 \mathrm{~g} \mathrm{~kg}^{-1}$, in dry matter of diets. Thus, the objectives of this study were to evaluate the effects of high levels of crude glycerin as a partial replacement of corn, in medium-yield dairy cows' diets on ruminal parameters, microbial yield, and in vitro greenhouse gases.

The Unesp/Jaboticabal Institutional Animal Care and Use Committee approved all the procedures adopted in this study (protocol No. 1892108). The research was conducted at Animal Unit of Digestive and Metabolic Studies and at the Greenhouse and Ingredients Laboratory from the Animal Science Department of São Paulo State University, Jaboticabal, Brazil.

Six multiparous ruminally cannulated lactating Holstein cows $(587 \pm 39 \mathrm{~kg}$ BW, $114 \pm 29$ DIM, and milk production of $20 \pm 1.5 \mathrm{~kg} \mathrm{~d}^{-1}$ ) were used in this study, in a replicated $3 \times 3$ Latin square design. Cows were paired according to initial weight, parity, and milk production.

Received 11 November 2015. Accepted 19 June 2016.

E.H.C.B. van Cleef, J.B.D. Sancanari, Z.F. Silva, A.P. D’Aurea, V.R. Fávaro, F.O.S. van Cleef, A.C. Homem Júnior, and J.M.B. Ezequiel. College of Agrarian and Veterinarian Sciences, São Paulo State University “Júlio de Mesquita Filho", Jaboticabal, São Paulo 14884-900, Brazil.

Corresponding author: E.H.C.B. van Cleef (email: ericvancleef@gmail.com).

Abbreviations: ADF, acid detergent fiber; BW, body weight; CP, crude protein; DIM, days in milk; DM, dry matter; DMI, dry matter intake; EE, ether extract; LAB, Liquid-associated bacteria; LAP, liquid-associated protozoa; ME, metabolizable energy; NDF, neutral detergent fiber; NFC, nonfiber carbohydrate; OM, organic matter; PAB, particle-associated bacteria; RDP, rumen degradable protein; RUP, rumen undegradable protein.

Copyright remains with the author(s) or their institution(s). Permission for reuse (free in most cases) can be obtained from RightsLink. 
Table 1. Ingredient and chemical composition of experimental diets containing increasing concentrations of crude glycerine.

\begin{tabular}{|c|c|c|c|}
\hline \multirow[b]{2}{*}{ Item } & \multicolumn{3}{|c|}{ Treatments $^{a}$} \\
\hline & G0 & G150 & G300 \\
\hline \multicolumn{4}{|l|}{ Ingredients (g kg $\left.{ }^{-1} \mathrm{DM}\right)$} \\
\hline Corn silage & 450 & 450 & 450 \\
\hline Corn grain & 365 & 193 & 28 \\
\hline Sunflower meal & 107 & 114 & 113 \\
\hline Corn gluten meal & 51 & 66 & 81 \\
\hline Urea & 5 & 5 & 6 \\
\hline Crude glycerin & 0 & 150 & 300 \\
\hline Mineral-vitamin premix ${ }^{b}$ & 23 & 23 & 23 \\
\hline \multicolumn{4}{|l|}{ Chemical composition } \\
\hline $\mathrm{CP}\left(\mathrm{g} \mathrm{kg}^{-1} \mathrm{DM}\right)$ & 144 & 143 & 141 \\
\hline $\mathrm{RDP}\left(\mathrm{g} \mathrm{kg}^{-1} \mathrm{DM}\right)$ & 98 & 97 & 95 \\
\hline RUP (g kg-1 DM) & 46 & 46 & 46 \\
\hline $\mathrm{NDF}\left(\mathrm{g} \mathrm{kg}^{-1} \mathrm{DM}\right)$ & 348 & 333 & 315 \\
\hline $\mathrm{ADF}\left(\mathrm{g} \mathrm{kg}^{-1} \mathrm{DM}\right)$ & 190 & 189 & 186 \\
\hline $\mathrm{NFC}^{c}\left(\mathrm{~g} \mathrm{~kg}^{-1} \mathrm{DM}\right)$ & 453 & 333 & 215 \\
\hline $\mathrm{EE}\left(\mathrm{g} \mathrm{kg}^{-1} \mathrm{DM}\right)$ & 32 & 26 & 21 \\
\hline ME (Mcal kg-1 DM) & 2.8 & 2.8 & 2.8 \\
\hline
\end{tabular}

${ }^{a}$ G0: control treatment; G150: addition of $150 \mathrm{~g} \mathrm{~kg}^{-1}$ crude glycerin; G300: addition of $300 \mathrm{~g} \mathrm{~kg}^{-1}$ crude glycerin.

${ }^{b}$ Composition of mineral-vitamin premix $\left(\mathrm{g} \mathrm{kg}^{-1}\right)=$ vitamin A: $200 \mathrm{kIU}$; vitamin D: $60 \mathrm{kIU}$; vitamin E: $60 \mathrm{IU}$; Ca: 190 g; P: 73 g; Na: 62 g; Mg: 44 g; Cl: 90 g; S: 30 g; Zn: $1350 \mathrm{mg}$; Mn: $940 \mathrm{mg}$; Co: $3 \mathrm{mg}$; Cu: $340 \mathrm{mg}$;: $16 \mathrm{mg}$; Se: $16 \mathrm{mg}$; Fe: $1064 \mathrm{mg}$; F: $730 \mathrm{mg}$.

${ }^{c} \mathrm{NFC}=100-(\% \mathrm{CP}+\% \mathrm{NDF}+\% \mathrm{ash}+\% \mathrm{EE})$.

After lactation peak, each pair was randomly assigned to one of the three experimental diets and progressed through the three $21 \mathrm{~d}$ periods until everyone had received all treatments. Cows were housed in individual tie stall $(1.5 \mathrm{~m} \times 1.9 \mathrm{~m})$ equipped with individual feed bunks and waterers.

The experimental diets were composed of corn silage, cracked corn grain, sunflower meal, corn gluten, urea, mineral premix, and 0 (G0), 150 (G150), or $300 \mathrm{~g} \mathrm{~kg}^{-1}$ (G300) crude glycerin (Table 1). Corn silage was topdressed with crude glycerin and then mixed with the concentrate at the time of feed delivery. The crude glycerin used in this experiment was soybean based and composed of $83 \mathrm{~g} \mathrm{~kg}^{-1}$ glycerol, $89 \mathrm{~g} \mathrm{~kg}^{-1} \mathrm{DM}, 6 \mathrm{~g} \mathrm{~kg}^{-1}$ $\mathrm{NaCl}$, and less than $0.01 \mathrm{~g} \mathrm{~kg}^{-1}$ methanol.

The methodology of ruminal microbial isolation used in this trial was described by Martin et al. (1994). Approximately $3 \mathrm{~kg}$ of ruminal content was sampled from the rumen, between the cranial and ventral coronary pillars at $0,4,9$, and $15 \mathrm{~h}$ after morning feeding. An additional sample of $100 \mathrm{~g}$ of ruminal content was collected to determine $\mathrm{pH}$ values and ammonia nitrogen concentrations. To avoid any interference in ruminal function, only one sample was collected per day, between d 18 and d 21 of each experimental period.
The ruminal content was strained through four layers of cheesecloth to separate liquid and solid phases. From solid phase, $200 \mathrm{~g}$ was weighed and $30 \mathrm{~g}$ was used for $\mathrm{DM}$ analysis, and $170 \mathrm{~g}$ was used for isolation of particle-associated bacteria (PAB). The solid material was initially manually washed with a prewarmed $\left(39^{\circ} \mathrm{C}\right)$ Coleman solution $\left(0.63 \mathrm{~g} \mathrm{~kg}^{-1} \mathrm{~K}_{2} \mathrm{HPO}_{4}, 0.5 \mathrm{~g} \mathrm{~kg}^{-1} \mathrm{KH}_{2} \mathrm{PO}_{4}\right.$, $0.065 \mathrm{~g} \mathrm{~kg}^{-1} \mathrm{NaCl} \cdot 6 \mathrm{H}_{2} \mathrm{O}, 0.09 \mathrm{~g} \mathrm{~kg}^{-1} \mathrm{MgSO}_{4} \cdot 7 \mathrm{H}_{2} \mathrm{O}$, and $0.5 \mathrm{~g} \mathrm{~kg}^{-1}$ cysteine hydrochloride), using a ratio of $1 \mathrm{~g}$ solid to $4 \mathrm{~g}$ saline solution. The content was filtered through a nylon filter $(100 \mu \mathrm{m})$, and the filtrate was then centrifuged at room temperature $(1000 \mathrm{~g}$, for $10 \mathrm{~min}$, at room temperature). The pellet of small particles obtained was added to the content retained on the filter. This combined material was suspended in a precooled Coleman solution $\left(4^{\circ} \mathrm{C}\right)$ and homogenized at $200 \mathrm{rpm}$ for 5 min using a Stomacher device (Seward and Co., London, UK). Material was filtered and the solids retained were discarded. Filtered was centrifuged $\left(1000 \mathrm{~g}\right.$, for $10 \mathrm{~min}$, at $4^{\circ} \mathrm{C}$ ) and the supernatant was centrifuged $\left(27000 \mathrm{~g}\right.$, for $30 \mathrm{~min}$, at $\left.4^{\circ} \mathrm{C}\right)$. Resulting pellet was considered as the PAB. Bacterial material was transferred to $100 \mathrm{~mL}$ plastic flasks and dried at $55^{\circ} \mathrm{C}$ for 72 h. Flasks with the dried PAB were weighed and reserved for analysis of DM, ash, and $\mathrm{N}$ (Association of Official Analytical Chemists 1990).

From the liquid phase, $700 \mathrm{~mL}$ was diluted with a prewarmed $\left(39^{\circ} \mathrm{C}\right)$ Coleman solution (1:1) and incubated in a water bath at $39^{\circ} \mathrm{C}$ for $30 \mathrm{~min}$, until the flocculation was completed. After $25 \mathrm{~min}$ of incubation, $1 \mathrm{~g} \mathrm{~L}^{-1}$ glucose was added to separate the protozoa from the rest of ruminal liquid. After the separation, $400 \mathrm{~mL}$ of clarified fluid was centrifuged (1000g, for $10 \mathrm{~min}$, at room temperature), and the pellet of liquid-associated protozoa (LAP) was recovered. Pellets were washed with a prewarmed saline solution $\left(39^{\circ} \mathrm{C}\right.$ ) and filtered through a $20 \mu \mathrm{m}$ nylon filter.

Liquid-associated bacteria (LAB) were recovered by centrifuging the protozoa-free supernatant (15 $000 \mathrm{~g}$, for $20 \mathrm{~min}$, at $4{ }^{\circ} \mathrm{C}$ ). Pellets of LAP and LAB were transferred to $100 \mathrm{~mL}$ plastic flasks and dried at $55^{\circ} \mathrm{C}$ for $72 \mathrm{~h}$. Flasks with dried microorganisms were weighed and reserved for analysis of DM, ash, and N.

For the evaluation of ruminal parameter, $100 \mathrm{~g}$ of ruminal content was strained through four layers of cheesecloth to separate liquid and solid phases. Ammonia concentrations and $\mathrm{pH}$ values were immediately measured after rumen fluid sampling and separation. The $\mathrm{pH}$ was determined using a digital $\mathrm{pH}$ meter and the ammonia using a microkjeldhal device, using $5 \mathrm{~mL}$ of $2 \mathrm{M} \mathrm{KOH}$, and distillation flux of $2 \mathrm{~mL} \mathrm{~min} \mathrm{~m}^{-1}$. The distilled was dropped into a $10 \mathrm{~mL}$ boric acid solution $\left(20 \mathrm{~g} \mathrm{~kg}^{-1}\right)$ and then titrated with $0.005 \mathrm{M} \mathrm{HCl}$.

For in vitro gas production trial, approximately $4 \mathrm{~kg}$ of ruminal content was manually collected and strained through four layers of cheesecloth. Strained rumen fluid mixed with McDougall's buffer in 2:1 ratio $(120 \mathrm{~mL}$ in 
Table 2. Dry matter intake, ruminal parameters, protozoal, and bacterial fractions and in vitro gas production in lactating Holstein cows fed diets supplemented with different amounts of crude glycerine.

\begin{tabular}{|c|c|c|c|c|c|c|}
\hline \multirow[b]{2}{*}{ Item } & \multicolumn{3}{|c|}{ Treatments $^{a}$} & \multicolumn{2}{|c|}{ Contrast, $P$-value } & \multirow[b]{2}{*}{ SE } \\
\hline & G0 & G15 & G30 & $\mathrm{G} 0 \times \mathrm{G}^{b}$ & $\mathrm{G} 15 \times \mathrm{G}^{3} 0^{c}$ & \\
\hline $\mathrm{DMI}^{d}\left(\mathrm{~kg} \mathrm{~d}^{-1}\right)$ & 17.8 & 17.2 & 15.0 & 0.02 & 0.01 & 1.48 \\
\hline \multicolumn{7}{|c|}{ Ruminal parameters } \\
\hline $\mathrm{pH}$ & 6.0 & 5.9 & 5.9 & 0.47 & 0.91 & 0.05 \\
\hline $\mathrm{NH}_{3}-\mathrm{N}\left(\mathrm{mg} \mathrm{dL}^{-1}\right)$ & 28.1 & 20.3 & 20.9 & 0.04 & 0.65 & 1.80 \\
\hline \multicolumn{7}{|l|}{$\begin{array}{l}\text { Microorganisms } \\
\mathrm{LAB}^{e}\left(\mathrm{mg} \mathrm{L}^{-1}\right)\end{array}$} \\
\hline $\mathrm{DM}$ & 1575.9 & 1155.1 & 1235.9 & $<0.0001$ & 0.24 & 56.79 \\
\hline $\mathrm{OM}$ & 1165.9 & 815.3 & 852.3 & $<0.0001$ & 0.56 & 46.19 \\
\hline $\mathrm{N}$ & 151.6 & 114.5 & 117.9 & $<0.0001$ & 0.65 & 5.27 \\
\hline \multicolumn{7}{|l|}{$\operatorname{PAB}^{f}\left(\mathrm{mg} \mathrm{kg}^{-1}\right)$} \\
\hline DM & 5442.5 & 4957.9 & 5837.8 & 0.15 & 0.004 & 454.78 \\
\hline $\mathrm{OM}$ & 4894.6 & 4025.3 & 4786.3 & 0.18 & 0.008 & 390.40 \\
\hline $\mathrm{N}$ & 573.6 & 486.5 & 555.7 & 0.31 & 0.06 & 41.29 \\
\hline \multicolumn{7}{|l|}{$\operatorname{LAP}^{g}\left(\mathrm{mg} \mathrm{L}^{-1}\right)$} \\
\hline $\mathrm{DM}$ & 1800.6 & 1785.8 & 1910.9 & 0.17 & 0.54 & 62.34 \\
\hline $\mathrm{OM}$ & 765.4 & 854.3 & 812.1 & 0.37 & 0.10 & 29.76 \\
\hline $\mathrm{N}$ & 113.3 & 121.0 & 114.7 & 0.23 & 0.32 & 4.31 \\
\hline \multicolumn{7}{|l|}{ Gas production } \\
\hline Total (mL g $\left.{ }^{-1} \mathrm{DM}\right)$ & 30.7 & 22.5 & 28.4 & 0.25 & 0.27 & 7.90 \\
\hline $\mathrm{CH}_{4}\left(\mathrm{~mL} \mathrm{~g}^{-1} \mathrm{DM}\right)$ & 5.1 & 4.4 & 7.2 & 0.52 & 0.04 & 2.08 \\
\hline $\mathrm{CO}_{2}\left(\mathrm{~mL} \mathrm{~g}^{-1} \mathrm{DM}\right)$ & 18.9 & 15.8 & 17.5 & 0.52 & 0.66 & 6.30 \\
\hline $\mathrm{CO}_{2} / \mathrm{CH}_{4}$ & 3.7 & 3.6 & 2.6 & 0.67 & 0.03 & 0.96 \\
\hline 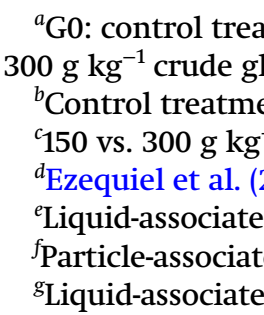 & $\begin{array}{l}\text { G150: ac } \\
\text { lycerin } \\
\text { glyceri } \\
\text { ria. } \\
\text { eria. } \\
\text { zoa. }\end{array}$ & $\begin{array}{l}\text { tion of } 1 \\
\text { atments }\end{array}$ & $\mathrm{g} \mathrm{kg}^{-1} \mathrm{c}$ & le glycerir & G300: additio & \\
\hline
\end{tabular}

total volume) was transferred to $250 \mathrm{~mL}$ plastic erlenmeyers containing $1.7 \mathrm{~g}$ (DM basis) of each experimental diet, to keep a 1:8 ratio of sample and inoculum. The erlenmeyers were purged with $\mathrm{CO}_{2}$, capped with silicon stoppers, and attached to gasometers made of plastic pipe and $500 \mathrm{~mL}$ plastic bottles. The erlenmeyers were incubated in a water bath at $39{ }^{\circ} \mathrm{C}$ for a $12 \mathrm{~h}$ period. The total gas production was measured using a graduated ruler and correlated with a standard curve previously built to convert height in volume, according to the bottle area. The gas was sampled with a $1 \mathrm{~mL}$ syringe and $0.5 \mathrm{~mL}$ was immediately injected into a gas chromatograph (Trace GC Ultra, Thermo Scientific) to evaluate the concentrations of $\mathrm{CO}_{2}$ and $\mathrm{CH}_{4}$. The GC was equipped with a Porapak column and molecular sieve. The oven temperature was set to $70{ }^{\circ} \mathrm{C}$, and the injector temperature used was at $110{ }^{\circ} \mathrm{C}$. The carrier gas used was argon, with

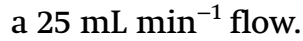

Data were analyzed as a replicated $3 \times 3$ Latin square design using PROC MIXED for repeated measures of
SAS (version 9.1; SAS Institute, Inc., Cary, NC, USA). Orthogonal contrasts were used to determine the effects of crude glycerin and the effect of $150 \mathrm{vs} .300 \mathrm{~g} \mathrm{~kg}^{-1}$ crude glycerin. For the analysis of repeatedly measured variables, sampling time and time $\times$ treatment interaction terms and a repeated-measures statement with the unstructured covariance structure, based upon its smallest Akaike's information criterion value, were used. Significance was defined as $P<0.05$ and trends as $0.05 \leq P \leq 0.10$. Values are reported as least-squares means and associated standard errors.

There was no interaction of treatments and sampling time for all variables evaluated in this experiment. No differences were observed among treatments for ruminal pH (average 6.93). Ruminal ammonia decreased $(P=0.04)$, when control treatment was compared with treatments with glycerin (Table 2), but the increase from 150 to $300 \mathrm{~g} \mathrm{~kg}^{-1}$ crude glycerin in the diet did not change ruminal ammonia concentrations (average $20.6 \mathrm{mg} \mathrm{dL}^{-1}$ ). The $\mathrm{pH}$ values observed in the present trial 
agree with previous studies in which glycerin was supplemented to dairy cows (Boyd et al. 2013). The average of 5.93 indicates that even with $300 \mathrm{~g} \mathrm{~kg}^{-1}$ crude glycerin supplementation, the $\mathrm{pH}$ ranges from 5.8 to 6.2, which is considered normal for lactating dairy cows. The lower concentration of ruminal ammonia in G150 and G300 can be attributed to the lower DMI observed in those treatments (Table 2), as reported by Ezequiel et al. (2015). Ruminal ammonia is the main source of nitrogen of several cellulolytic bacteria, and it could be the reason for lower production of PAB in G150. Previous studies report similar effects of glycerin on ruminal ammonia concentrations. Shin et al. (2012) fed lactating cows with $100 \mathrm{~g} \mathrm{~kg}^{-1}$ glycerin, in corn silage or cottonseed hullsbased diets, and observed reduction of ruminal ammonia in animals fed the glycerin treatment, in both conditions.

The addition of crude glycerin, regardless the concentration, decreased $(P<0.0001)$ the DM, OM yield, and $\mathrm{N}$ contents of LAB (Table 2); however, no changes were observed between G150 and G300. The amount of PAB was similar when control treatment was compared with glycerin treatments together; however, G150 promoted less PAB than G300 ( $P=0.004)$. The nitrogen content of PAB tended to be lower $(P=0.06)$ in treatments with $150 \mathrm{~g} \mathrm{~kg}^{-1}$ glycerin compared with G300, and no difference was observed between control treatment and glycerin treatments. There were no differences among treatments in the amount of LAP, showing $1832.4 \mathrm{mg} \mathrm{DM} \mathrm{L}^{-1}$ and $116.3 \mathrm{mg} \mathrm{N} \mathrm{L}^{-1}$, on average. Manipulation of dietary factors may alter chemical composition of bacteria, bacterial attachment on rumen feed particles, and the relative proportions of liquid and PAB. The mechanism of action of crude glycerin on the populations of bacteria is still unclear and may be due to the formation of an unfavorable ruminal environment in terms of osmolality, encapsulation of feed particles avoiding microorganism to adhere, and competition of bacteria or substrate preference.

The negative effect of crude glycerin on solidassociated bacteria, observed in G150 from present study, is very important because bacterial colonization of ruminal particles is an important prerequisite for fiber degradation. On the other hand, the negative effect of crude glycerin inclusion on LAB yield was probably due to the reduction in DM intake and changes in ruminal osmolality. Moreover, considering that approximately $43 \%$ of glycerol is absorbed through the ruminal wall (Krehbiel 2008), it probably contributes to the reduction of subtract available to LAB. The lack of effect of crude glycerin on liquid-associated protozoa disagrees with the results presented by Fávaro et al. (2014) who observed linear decrease of LAP, when feeding crossbred steers with $0,50,100,150$, or $200 \mathrm{~g} \mathrm{~kg}^{-1}$ crude glycerin. In current study, it expected a reduction in LAP yield due to the reduction of LAB, which is engulfed by protozoa as its main protein source.
The production of methane (Table 2) was not affected by glycerin supplementation ( $P=0.52)$, though G300 showed higher production than G150 $(P=0.04)$. Nonetheless, the production of $\mathrm{CO}_{2}$ was similar among treatments. These results caused the lower $\mathrm{CO}_{2}$ to $\mathrm{CH}_{4}$ ratio for $\mathrm{G} 300$ compared with the other treatments $(P=0.03)$. The similar $\mathrm{CO}_{2}$ production among treatments was associated with the increased production of $\mathrm{CH}_{4}$ in treatment $\mathrm{G} 300$ compared with treatment G150, decreasing the $\mathrm{CO}_{2} / \mathrm{CH}_{4}$ ratio in treatment G300. From the total gas produced, $62 \%, 70 \%$, and $62 \%$ corresponded to $\mathrm{CO}_{2}$, and $17 \%, 20 \%$, and $25 \%$ to $\mathrm{CH}_{4}$, respectively for G0, G150, and G300. This means that after $12 \mathrm{~h}$ of ruminal incubation, the G300 treatment provided gas production proportionally richer in methane than the other treatments. The hypothesis is that the presence of glycerol in the rumen favored other pathways of action of methanogenic bacteria, with elevated production of methane, which was demonstrated in this study. Justifying this statement, Jarvis et al. (1997) mentioned that there is formation of formate and ethanol from glycerol molecule in the rumen. In turn, the formate produced turns into methane. In addition, large amounts of ethanol are oxidized to acetate in the rumen (Pradhan and Hemken 1970), a process that releases reducing equivalents used for the production of $\mathrm{CH}_{4}$.

The use of high concentrations of crude glycerin $\left(150\right.$ or $300 \mathrm{~g} \mathrm{~kg}^{-1}$ ) in diets for lactating dairy cows reduces liquid- and solid-associated bacteria yield and ammonia nitrogen without affecting ruminal $\mathrm{pH}$. Nonetheless, $300 \mathrm{~g} \mathrm{~kg}^{-1}$ crude glycerin increases in vitro methane production.

\section{Acknowledgements}

The research was funded by Fundação de Apoio à Pesquisa do Estado de São Paulo (FAPESP 08/55766-0) and Caramuru Alimentos S.A.

\section{References}

Association of Official Analytical Chemists (AOAC). 1990. Official method of analysis. 15th ed. AOAC, Arlington, VA.

Boyd, J., Bernard, J.K., and West, J.W. 2013. Effects of feeding different amounts of supplemental glycerol on ruminal environment and digestibility of lactating dairy cows. J. Dairy Sci. 96: 470-476. doi:10.3168/jds.2012-5760. PMID:23182356.

Ezequiel, J.M.B., Sancanari, J.B.D., Machado Neto, O.R., Silva, Z.F., Almeida, M.T.C., Silva, D.A.V., van Cleef, F.O.S., and van Cleef, E.H.C.B. 2015. Effects of high concentrations of dietary crude glycerin on dairy cow productivity and milk quality. J. Dairy Sci. 98: 8009-8017. doi:10.3168/jds.2015-9448. PMID:26298757.

Fávaro, V.R., Ezequiel, J.M.B., D’Aurea, A.P., Sancanari, J.B.D., Homem Júnior, A.C., Van Cleef, E.H.C.B., and Santos, V.C. 2014. A utilização de glicerina em dietas para bovinos altera a microbiota ruminal. Arch. Bras. Med. Vet. Zootec. 66: 1504-1512. doi:10.1590/1678-6654.

Jarvis, G.N., Moore, E.R.B., and Thiele, J.H. 1997. Formate and methanol are the major products of glycerol fermentation by a Klebsiella planticola strain isolated from red deer. J. Appl. 
Microbiol. 83: 166-174. doi:10.1046/j.1365-2672.1997.00217.x. PMID:9281820.

Krehbiel, C.R. 2008. Ruminal and physiological metabolism of glycerin. J. Anim. Sci. 86 (Suppl. 1): 392 (Abstr.).

Martin, C., Willians, A.G., and Michalet-Doreau, B. 1994. Isolation and characteristics of the protozoal and bacterial fractions from bovine ruminal contents. J. Anim. Sci. 72: 2962-2968.

Pradhan, K., and Hemken, R.W.1970. Utilization of ethanol and its effect on fatty acid patterns in ruminants. J Dairy Sci.
53: 1739-1746. doi:10.3168/jds.S0022-0302(70)86472-4. PMID: 5530981.

Rémond, B., Souday, E., and Jouany, J.P. 1993. In vitro and in vivo fermentation of glycerol by ruminal microbes. Anim Feed Sci Technol. 41: 121-132. doi:10.1016/0377-8401(93)90118-4.

Shin, J.H., Wang, D., Kim, S.C., Adesogan, A.T., and Staples, C.R. 2012. Effects of feeding crude glycerin on performance and ruminal kinetics of lactating Holstein cows fed corn silageor cottonseed hull-based, low-fiber diets. J. Dairy Sci. 95: 4006-4016. doi:10.3168/jds.2011-5121. 